\title{
Beyond Babylon
}

\section{Geographies of Conversion}

As a radical standpoint, perspective, position, "the politics of location" necessarily calls those of us who would participate in the formation of counterhegemonic cultural practice to identify the spaces where we begin the process of re-vision.

- BELL HOOKS

With music, mek we chant down Babylon

This music, mek we chant down Babylon

This music, come we chant down Babylon

-BOB MARLey, "CHANT DOWN BabyLON"

I heard Khanchuz before I saw him-his most recent gangsta-inspired Any Demon Killa beats accosting my ears through his car windows, alerting me to his imminent arrival. He parked, locked the doors of his metallic beige Cadillac, and swaggered slowly up Degnan Boulevard in Leimert Park Village-a historic black arts district in Los Angeles that continues to struggle against the twin forces of urban abandonment and encroaching gentrification. Standing at the opposite end of the block, I caught a glimpse of his faux diamond cross swinging gently across his chesta pendulum of light against the dark night as he passed a colorful mural bearing the words: "At the crossroads, a vision is shaped." Khanchuz greeted me with a hug before we turned the corner onto 43rd Place. Another sonic curiosity beckoned. This time inside Sonny's Spot - a small cavernous music club that hosted the longstanding "Poets Jazz House" and where the local Artists for Justice and Liberation collective previously held action meetings to "Save Leimert Park." The interior walls, tagged with layers of writing and adorned with various jazz memorabilia, provided our backrest as an elderly African American pianist improvised to the tune "Nina's Dream." Overhead, King Oliver's Creole Jazz Band gazed down at his dancing fingers from a washed-out black and white photograph across the room. 
Our night crawl continued as we passed the vaudeville era and then boardedup Vision Theater-a neighborhood movie palace originally known as Leimert Theater that was converted into a Jehovah's Witness church under the name The Watchtower. Purchased and renamed the Vision Theater by actress Marla Gibbs in 1990, the property was foreclosed on and the city took ownership in 2000. One storefront down, we reached our destination: KAOS Network, a cultural center that was home to the infamous weekly underground hip hop open mic, Project Blowed, that gave rise to MCs and rap groups such as Aceyalone, Freestyle Fellowship, Medusa, and Jurassic Five. But on that balmy fall evening, KAOS Network was hosting a different brand of hip hop-a religious open-mic called Klub Zyon where local gospel rappers gathered every month to "chant down Babylon" through biblically inspired rhymes. Zyon, the open mic's founders explained to me, was where we were going - the ultimate place, a spiritual homeland for wandering travelers.

Before Khanchuz got saved, he was at Project Blowed rapping about gangbangin', both on stage and in the freestyle battles that would spill out onto the street corner and linger into the break of day. As we walked through the scattered dreams, memories, and visions of Leimert Park and finally came face to face with the front door of KAOS Network, Khanchuz stepped back in silent wonder as he reflected on the conversion of both his soul and this place.

\section{CONVERSION AS SPATIAL PRACTICE}

Holy hip hop practitioners, through their musical practices and discourses, worked with and on what I refer to as the "living architecture" of the city to create sites of gospel rap production. Gospel rap artists perceived and performed place as a converting body and a site for the potential conversion of religious subjects; they also experienced and enacted conversion as both a spiritual transformation and a spatial practice. Their spatial practices constituted the manifold ways in which holy hip hoppers moved through, used, altered, and made meaning out of space. ${ }^{1}$ Their spatial practices were especially critical in L.A.s terrains and conditions of uncertainty.

As previously argued, Los Angeles in the late 1980s and 1990s was wrought with social and environmental volatility. ${ }^{2}$ The Southland's morphing geography was in part due to the extent to which the deindustrialization of L.A., strict land ordinances and housing covenants, and inner-city neglect led to a lack of consolidating apparatuses that delineated regularities of territory in the city. Renovations and restructuring in the wake of the Watts riots and the 1992 riots along with the changing nature of Los Angeles churches, specifically the rise of megachurches, further complicated the city's shape-shifting landscapes. This instability was, at times, managed and manipulated by state bureaucracies and apparatuses to 
implement certain reforms. As Elana Zilberg argues, policing practices in L.A., such as gang injunctions, constituted a "technology of spatial legislation," creating certain segregations, marginalities, and foreclosures. ${ }^{3}$ And yet instability also provided the conditions of possibility for city dwellers to radically re-vision and transform the existing urban milieu. Holy hip hop practices formed a technology of spatial improvisation that produced new kinds of sacred space in the citywhat I call geographies of conversion.

During the five years I lived in Los Angeles (2003-8), holy hip hop comprised a highly complex field of practices that included music labels, local scenes, ministries, radio programs, award shows, and musical collectives that functioned in an astonishing variety of buildings and locations deemed both religious and nonreligious. And yet, their unique expressions were not always perceived positively by church communities or secular hip hop fans and artists. Existing oftentimes in between the club, the church, and the streets, gospel rap artists struggled to locate receptive audiences and find a true dwelling place-to find "Zyon." In fact, holy hip hop was one of the few black Christian musical practices where the churchoften referred to as the Body of Christ by both Catholics and Protestants-was not the primary location of power and performance. ${ }^{4}$ While many church leaders and congregants were condemning holy hip hop, many African American youth perceived the church as a "negative asylum."' Holy hip hoppers often sought refuge from its constraints, but nightclubs were not necessarily welcoming of Jesuscentered hip hop either. Female gospel MC B-Love cleared the dance floor after she performed holy hip hop at her sister's birthday party at a local club. "The party was dead after I got up there. People didn't want to hear about the healing power of Christ while they were drinking and partying. But maybe someone got touched." So where did holy hip hoppers find a sense of belonging?

This chapter explores some of the "key sites" of gospel rap fellowship and performance.? Three holy hip hop-inspired events in Los Angeles aimed to welcome and integrate diverse subjects and beliefs: The Row, a street corner in downtown L.A.s Skid Row converted into an "airborne" church service; Klub Zyon, a hip hopbased cultural center converted into a place of musical worship and religious fellowship; and Club Judah, a church sanctuary converted into a holy hip hop "club." These geographies of conversion, as they intersected with holy hip hoppers' own biographies of conversion, underscored music's role in the mutual construction of both the changing body of the city and the changing bodies inhabiting it. How did the space of a church, street corner, or club, reworked by the practices of gospel rap, serve as a site for the creation of new kinds of places of activity and interaction as well as new kinds of religious subjects? How did the lived and imagined geographies of holy hip hoppers in Los Angeles inform, define, and disrupt the socially constructed and policed boundaries between the sacred and the profane, Christianity and hip hop, ministry and entertainment, the church and the streets? 
What holy hip hoppers did physically and performatively to their urban surroundings through the cultural production of gospel rap was always in relation to the sedimented meanings and histories of specific places. Holy hip hop was actualized in the practices of creating and converting places not traditionally used for either hip hop or religious expression into locations that could house the interface of diverse social actors and sacred, secular, and profane elements. ${ }^{8}$ And yet, where gospel rap was performed and actualized mattered. Specific places (as always and already constituted by an arrangement of social relations, spatial imaginaries, and grounded, material realities) also affected the holy hip hoppers that sought to use, shape, and inhabit them. The embodied musical practices, spiritual practices, and spatial practices of holy hip hoppers were deeply enmeshed, acting as allied modalities of agency fleshing out different bodies of the city.

\section{MAPPING BLACK L.A.}

The history of black music in Los Angeles is one charged with race and religion, marked by extreme contrasts of both inter- and intracommunal integration and segregation, and inextricably embedded in the geopolitics of the ever-expanding and converting body of the city. Los Angeles is often articulated as a city of racial, class-based, and territorial divisions on the one hand, and cultural assimilation and multiculturalism on the other. Both narratives enunciate the entanglement of realities and myths of the city. Jacqueline DjeDje and Eddie Meadows, in their introduction to California Soul (1998), highlight the intersecting histories of migration to Los Angeles, dating as far back as the 1929 stock market crash, which resulted in policies (e.g., restrictive housing covenants) and obstacles that forced African Americans into segregated communities, affecting the possibilities of musical expression and exchange within the city. ${ }^{9}$ Los Angeles nightclubs have historically been one of the battlegrounds of such enduring patterns of racial discrimination and exclusion precisely because of the possibilities for mixing they can offer and inspire. Conversely, the church has often served as a haven of interracial, intergenerational encounter and a cultural resource in both everyday practice and scholarly discourse-a place that nurtured the artistic development and professionalism of black sacred music (i.e., gospel music).

Mark Anthony Neal argues that the church and the jook-joint (i.e., club) have historically been the two main centers of black life. ${ }^{10}$ In the holy hip hop scene, certain pastors, church members, community members, and hip hop artists articulated a separation between sacred and secular spaces, and specifically, between the church and the streets. The streets often represented the constitutive outside or immoral other against which certain church members defined the sanctity of the Christian church. "The street becomes a religious trope," writes Omar McRoberts in his ethnography of Chicago African American churches, 
"alternately embodying notions of irredeemable evil and combatable sin." clubs and churches have not always been clearly delineated spatial entities, and in fact, have often occupied the very same buildings.

In the face of such geographic segregations and exclusions from the larger public space, black Angelenos utilized city buildings in a variety of ways-ways that planners, builders, and owners may not have intended. Clubs, in mid-twentieth-century Los Angeles, as places where people of various racial and ethnic backgrounds could dance together and intermingle, were the target of systematic shutdowns and discriminatory policing tactics based on fears of interracial mixing. Ralph Eastman explains how after-hours black nightclubs in L.A., often referred to as "breakfast clubs," sprang up in "storefronts, back rooms, and second floors" as alternative places of music making, dancing, drinking, and socializing outside the legal reach of the racially charged policies structuring nightlife in Los Angeles. ${ }^{12}$ These clubs, Eastman argues, were where black musicians could partake in "unselfconscious experimentation" with "openness to new forms."13

Similar spatial practices were enacted in the block parties and schoolyard battles of early hip hop in the Bronx, where African American and Latino youth hooked up turntables, speakers, and microphones to street lampposts to party and purge on public grounds. Thus, a superficial or surface-level mapping of black musical locations does not account for the multiple uses and conversions of urban space that (have had to) occur behind walls, after hours, and therefore, out of sight. Eastman argues that Los Angeles's African American musical heritage has been "ignored and forgotten," referring to this absence as an "entrenched critical myopia." ${ }^{14}$ This lack of a particular kind of critical sight has rendered invisible certain key sites of black musical performance. The tendency of black music studies to both represent the church and the club (or the church and the streets) as a social binary of African American cultural life and to avoid examinations of nontraditional uses of space has led to a spatial bias that excludes valuable forms of music making in black communities. While academic and public discourses separate these sites, music sounds their entanglement, giving voice to lived spatial resonances. The blurring of spatial categories is constitutive of holy hip hop's geographies of conversion.

\section{BABYLON'S RACIAL AND SPIRITUAL CARTOGRAPHIES}

Place holds prominence in hip hop, from the territorial and regional affiliations of rap artists to the mythologizing of the "ghetto" in hip hop lyrics and in the greater public imagination. As Eithne Quinn writes in his seminal text on Los Angeles gangsta rap, "rappers responded to the uprooting of their communities by redoubling their claims on the 'hood." ${ }^{15}$ Murray Forman's work has brought a critical spatial awareness to the study of hip hop cultures. Forman argues that hip hop has been 
in a process of "going local" where representations of and contestations around turf, territory, and 'hood are inextricably enmeshed in the cultural production of the music. ${ }^{16}$ His examination unpacks the analytical categories of race, space, and place as they relate to the shifting scales of spatial discourses in rap music. Less examined are the everyday spatial practices of hip hop practitioners. However, he does open up possibilities for the exploration of specific hip hop cartographies that account for "fictive" or imagined mappings of the city (often through music and lyrics) as well as "actual" spatial practices in and across the city. Here, the meaning(s) people make from particular spaces are critical and contingent on a variety of linked social realities, including race, religion, class, and gender. Moving the focus from the Hip Hop Nation as a historical construct to hip hop as a "geo-cultural amalgamation of personages and practices that are spatially dispersed" ${ }^{17}$ allows us to interrogate the various geographies that hip hop practitioners - as "alternative cartographers" reimagine and remap..$^{18}$ If gangsta rap assembles "geographies of gangsta”, as Quinn suggests, holy hip hop's geographies of conversion constitute one of many diverse and intersecting hip hop geographies. ${ }^{19}$

As musical and spiritual cartographers, gospel rap artists sound out multilevel mappings of the city. On the surfaces of Los Angeles's church-laden streets, Khanchuz once mapped for me a cityscape of separation: "There is an aura of spiritual division here. There are so many churches and yet each church is separate from the next. L.A. is made up of churches, motels, and liquor stores. In Inglewood, you have church, motel, liquor store, church, motel, liquor store, liquor store." ${ }^{\circ}$ Mike Davis confirms, "Black small businesses have withered for lack of credit or attention from the city, leaving behind only liquor stores and churches." ${ }^{21}$ The topography of Inglewood articulated by Khanchuz, which is repeated in many other historically black neighborhoods throughout Los Angeles, reveals the proximity of "sacred" and "secular" spaces but occludes certain alliances, integrations, and manipulations of space that are socially and relationally produced by city inhabitants. ${ }^{22}$ In other words, what did this particular mapping conceal or leave out? Gospel rap soundings amplify other spaces and cartographies of black L.A.

And yet, Khanchuz's mapping forces us to consider the connotations of race, gender, and class that particular kinds of places evoke, where churches, motels, and liquor stores connote black religiosity, prostitution/promiscuity, alcoholism, and criminality. Michael Keith argues, "There is a racist discourse of depravity that draws its provenance from a racialised construction of a black urban Babylon." ${ }^{23}$ How we language our environment matters. "As vocabulary maps the city, it creates cartographies of the social." ${ }^{24}$ Whereas early L.A. gangsta rappers, such as N.W.A., sonically and visually mapped frenetic inner-city territories of poverty, policing, and violence-Compton, Watts, and Long Beach-gospel rappers remapped those same racialized territories using biblical metaphors and narratives of spiritual rebirth, most notably Babylon and Zion. ${ }^{25}$ Similarly, in the 1980s, East 
Coast Muslim MCs created a new spiritual geography of New York (or what was sometimes referred to by hip hop heads as Zoo York). The city was "rechristened via Islam's holiest sites, with Harlem becoming Mecca and Brooklyn becoming Medina" - another instance revealing the entanglement of hip hop, religiosity, and geography. ${ }^{26}$

Los Angeles, with Hollywood at its cultural and commercial center, was often imagined through holy hip hop lyrics and everyday speech as the biblical city of Babylon-a city of excessive luxury, sensuality, vice, and corruption. The Bible portrayed Babylon as a place of captivity or exile for the Jews after the ancient empire of Babylonia conquered Israel in sixth century B.C.E. The exilic experience of holy hip hoppers navigating and traversing religious, musical, and physical borderlands of Los Angeles's Babylon paralleled and remapped this ancient narrative of displacement. In American Babylon, Robert O. Self argues, "Babylon as both place and concept passed into the lexicon of radical black politics in the late 1960s, borrowed from African American religious traditions as well as from the Jamaican Rastafarians for whom Babylon denoted Western capitalism and imperialism." ${ }^{27}$ As the metaphor of Babylon connotes cynicism, it also articulates a hopeful belief in rebirth and recreation. In the 1979 reggae classic "Steppin' Out of Babylon," Marcia Griffiths sang, "I’ve got no alternative, in a Babylon, but I know, yes I know, there's a Mount Zion." Paul Gilroy, in a chapter that shares the same title as Griffiths' hit, further elaborates that Rastas adhere to a worldview that "identifies the present state of oppression as a cohesive human creation-Babylon system-but simultaneously acknowledges the potential power of working people to transform it." ${ }^{28}$ Holy hip hoppers followed in this spiritual and musical diasporic tradition of transformation-of building Zyon in Babylon.

Getting beyond myopic mappings and instead "under the skin of the city," as Keith states, is in part a task of unmasking the "hidden racialized genealogies" that structure our ways of analyzing the city. ${ }^{29}$ It also involves tuning in to spatial practices-how holy hip hoppers sonically produced and spatially enacted geographies of conversion.

\section{SKID ROW AND THE “AIRBORNE CHURCH”}

Many gospel hip hop artists preferred not to perform in churches, not only because of their evangelical impulse to preach to the "unsaved" but also because they felt artistically limited and monitored inside church walls. At times, the performance of gospel hip hop came across as a particular kind of indirect resistance to or critique of the traditional church and its "outdated" and exclusionary practices. Gospel rappers also felt performatively restrained, which was ironic considering the emotive, expressive, and physical intensity of most African American religious worship. B-Love, a female gospel hip hop artist with the Los Angeles collective 
Hip Hopposite, felt that she always had to warn the congregation ahead of time, beseeching them to try to listen past their assumptions about hip hop to the spiritual message within her rhymes. She once rapped to me over the phone: "The four walls ain't the only way to reach a soul that's got outta the box. That's why I hip hop, and it don't stop, don't stop." She also grew weary of being the musical aberration of a given church service-the hip hop element that felt outside of, rather than welcome within, an overarching gospel aesthetic. Other artists spoke about the physical constraints and challenges of performing hip hop in churches, depending on the size of the pulpit area, where congregation members sit in relation to them, and the quality and capability of the church's sound system.

Those who have attempted to bring hip hop into the church have encountered other institutional and aesthetic challenges. As illustrated in the previous chapter on the Hip Hop Church L.A., the development of hip hop ministries housed within traditional churches engenders a complex web of power relations between proponents and critics of holy hip hop. In the song "Tambourine," Celah of Hip Hopposite states: "Every year, man, in L.A. holy hip hop and gospel MCs get so much opposition from the church." Further, numerous hip hop ministry leaders explained to me that they felt unwelcome, monitored, and surveyed as leaders of the "traditional" church would often "drop in," conspicuously and inconspicuously, during hip hop services to "check up" on their activities. ${ }^{30}$ At hip hop services I attended, the leaders of the traditional church would sometimes walk in late, sit in the back pews, and often portray a stoicism and sternness at odds with the playful and lively nature of the hip hop service. But Celah also critiqued the growing trend of hip hop ministries and churches:

I'm about to be very honest. Hip hop churches to me are very very corny. That's as corny as they get. I know they trying to reach people that need to be reached. I believe the Word reaches people. The Crossover Church in Florida in the one real hip hop church. There's Christian graffiti. The pulpit is a big spray paint can and they got turntables and all this stuff. They actually converted it and made it hip hop. ${ }^{31}$

In one of the harsher critiques of the Christian church, Cue, self-titled "Pastorfarian" and now a member of the Christian rap group Asylumz, stated,

So the church has become more like a negative asylum and I wouldn't say all churches, but most of them, they've become like a prison. They're supposed to be like a place that you can go to get help and be rehabilitated. That's why we call our group Asylumz. So I don't feel like I'm going to church just because I went to the church building, I feel like I'm going to church when I sit down face to face with somebody in the context of where they are, wherever they are ... So we still have to deal with the stigma, especially in the urban church, that goes with hip hop and gospel hip hop. You still have to go to bat with some heads-people preaching that it's the devil's music and all that. But I tell gospel hip hoppers, you know, why people haven't been 
responding, because you're all so busy trying to get the church to accept you instead of . . . Hip hop is made for the streets. We should be out in the streets reaching people. The church will come because the church always follows the movement. So why should we sit there and get the church to accept us? We don't need the church to accept us. ${ }^{32}$

In the spirit of this assessment, Cue, along with members of the New Song church (of which he is also a member) and his gospel hip hop group, began holding an outdoor church service every Friday night on the streets of Skid Row in downtown Los Angeles where sidewalks are lined with cardboard boxes, shopping cars, and makeshift tents. The blocks that comprise Skid Row, formerly agricultural lands until the 1870 s with the advent of railroad lines in Los Angeles, have been home to a diverse and ever-changing assemblage of low-level offenders, alcoholics and drug addicts, migrants, veterans, mentally ill and handicapped patients who have been "dumped" there by local hospitals, and folks just down on their luck. ${ }^{33}$ Cue has been committed to working with these urban communities as "evangelicals miss what's going on in the streets." ${ }^{34}$

While dangers and temptations pervade Skid Row, it is a place that also offers help and services in the form of food, counseling, and spiritual support. Cue's open-air church meets at the corner of Wall and Winston Streets-an intersection in the heart of Skid Row and rife with various forms of hustling due to the curved nature of the streets, preventing one from being able to see down to the other end of the block. Rain or shine, Cue often preaches from a black music stand under a street lamp surrounded by barricaded storefronts. Some people stand. Others sit in fold-up chairs that have been brought by volunteers.

With a population of almost twenty thousand-one of the largest stable populations of homeless in the United States-it is difficult to predict who might show up or what might occur during Friday night services. Recently, a homeless man burst into spontaneous song. Another woman gave her life to Christ from the balcony of a nearby building. "The gospel is airborne," as Cue once remarked. "You never know where it's going to land." ${ }^{35}$ For certain hip hop-loving Skid Row residents, the gospel landed in 2012 when renowned rap group Public Enemy visited Skid Row on the weekend of Martin Luther King Jr.s birthday and just twenty years after the riots, performing their Nation of Islam-inspired hip hop for local residents in an effort to spotlight the political and economic plight of Los Angeles's homeless. Cue continues to advocate on behalf of homeless populations and was an invited speaker at the 2016 homeless awareness rally at the University of Southern California.

The concept of an "airborne church" is really nothing new. The early religious gatherings of enslaved Africans in brush harbors-often referred to as the "invisible church"-provide an early example of creating church in the open air. ${ }^{36}$ Cue elaborated: 


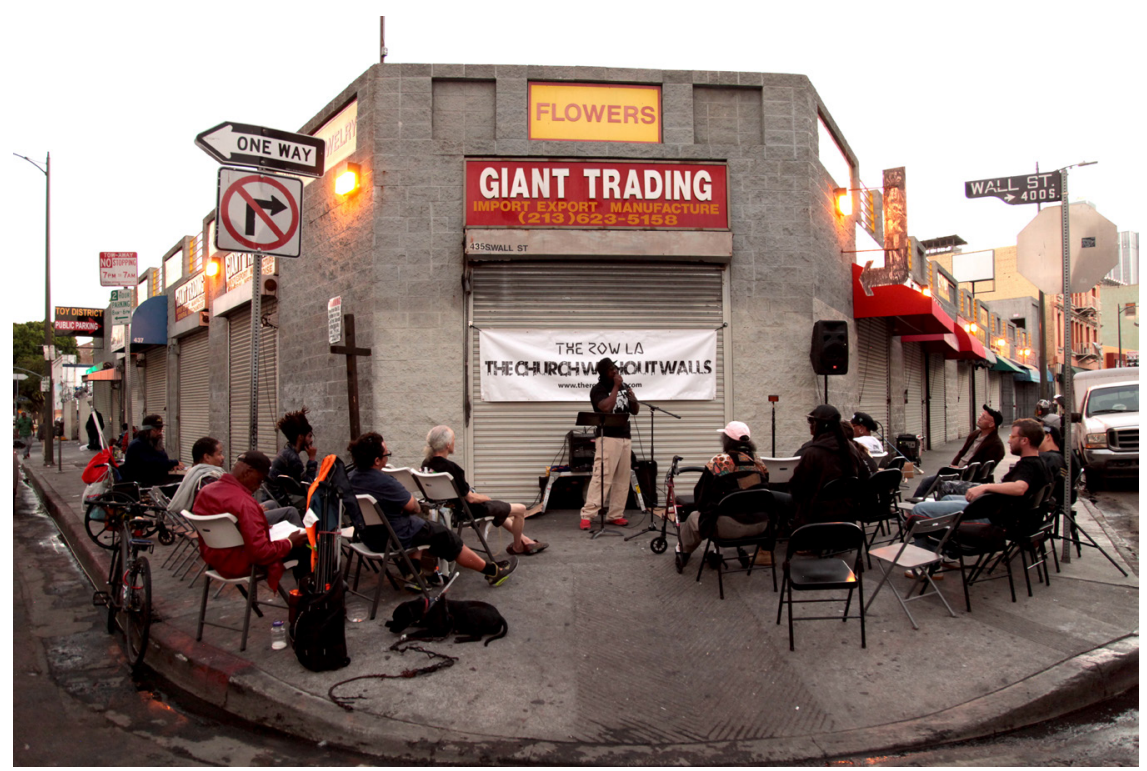

FIGURE 8. Cue Jn-Marie preaching at The Row ("The Church Without Walls") on Los Angeles's Skid Row, c. 2016. Photo courtesy of Ariel Blandford for the Center for Religion and Civic Culture at the University of Southern California.

We call it The Row. It's not a building but we call it the church without walls-the church moving. The street that we preach at on Skid Row is a major crack vein-drug vein. There's no real format to it. We preach the word and sometimes we'll do a song or someone from the street will just sing a gospel song. It's crazy the way it happens. After the Word we feed the people and eat with them because we want to be a part of their community as well. We don't just want to make them our project. People are not projects. We have a community of people now. If we would love people, then the church would go airborne, no matter where you are, there would be church. So that's what Asylumz is; it's a place of refuge. So even the name is deep in meaning. ${ }^{37}$

The Row illustrates the way that certain gospel rappers collapse people and place. Cue's statement asserts that it is people who are an embodiment of the church and that Asylumz - a group of people-is actually a place of refuge. Gospel hip hop artists perform a conscious expansion of the sacred beyond the church walls to other social arenas in both their discourses and practices; they spatialize holy hip hop in clubs, schoolyards, living rooms, street corners, cyberspace, radio airwaves, and public access TV shows. The Row, as a church without walls, holds certain implications for experiencing the city as a constantly converting body and the manner in which gospel hip hop artists hold out the same potential for the conversion of space as they do for the conversion of souls. 


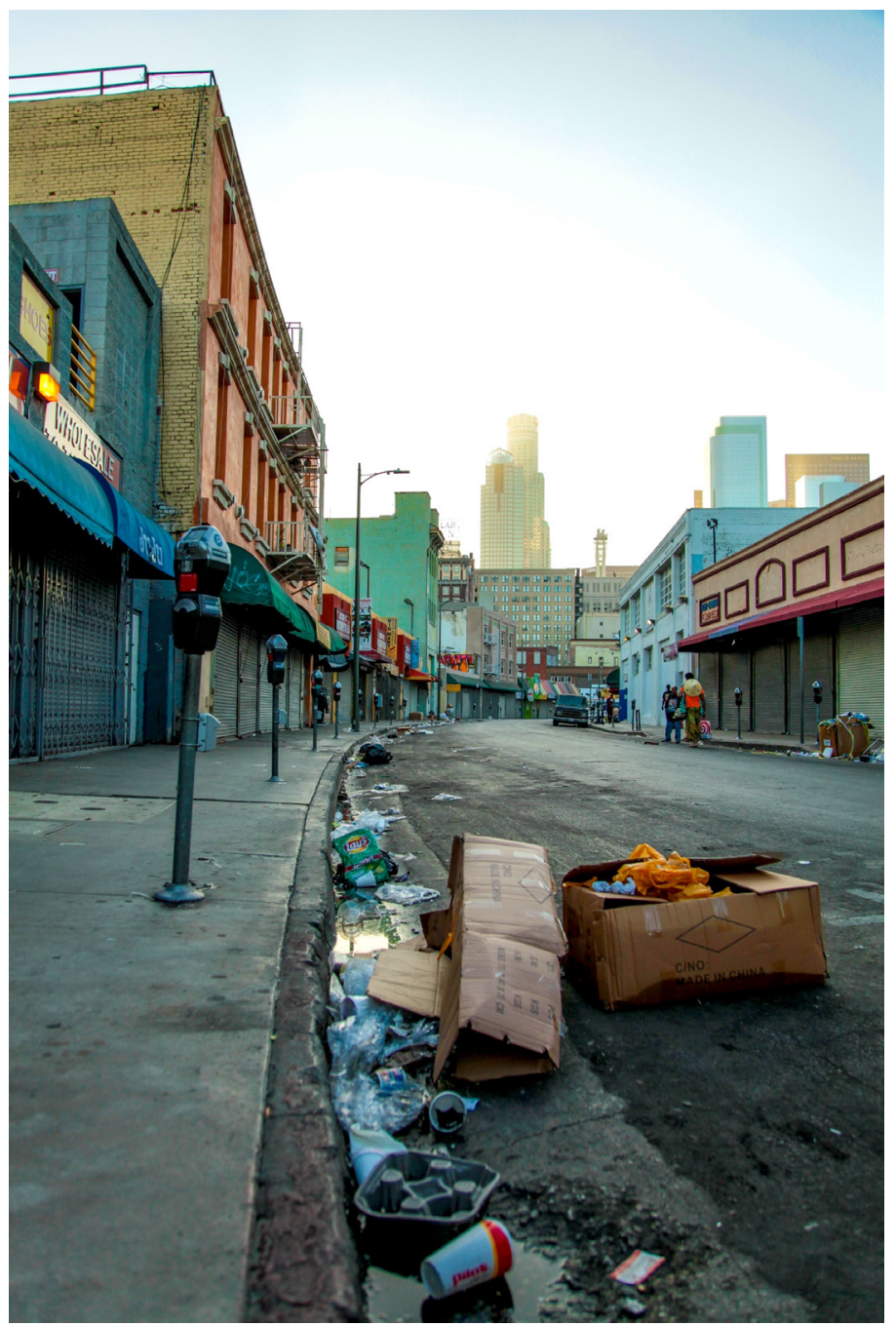

FIGURE 9. The view down Winston Street from the corner where The Row takes place every Friday night on Skid Row. Photo courtesy of Ariel Blandford for the Center for Religion and Civic Culture at the University of Southern California.

During the several years that I attended holy hip hop events, gospel rap artists generally preferred "mixed" events that embodied heterogeneity and promoted an individual's process of becoming in both a musical and religious sense..$^{38}$ Although, this was not always what was actualized at these events, and the outcomes of such 
gatherings sometimes served to strengthen the very discursive, musical, spatial, and imagined borders they were trying to dismantle. I now turn to two ongoing events or provisional sites of holy hip hop music: Klub Zyon and Club Judah. They both exist at the intersections of multiple fields of power, juxtaposing and integrating hip hop space, church space, and city space in experimental and everchanging ways.

\section{KLUB ZYON CROSSROADS}

Klub Zyon, as previously mentioned, was a monthly open mic that took place on every third Friday at KAOS Network-a cultural center established in 1984 in Leimert Park by filmmaker and activist Ben Caldwell. Cue founded the event in 2006 through his nonprofit organization the S.H.A.W. (sports, health, arts, and well-being) Community Transformation Corporation in the Crenshaw community of Los Angeles with the mission to provide an artistic meeting ground for different bodies and beliefs in the city. This vision of encounter and integration was realized and experienced in certain moments, however brief; other times, it stood as a spatial and social metaphor of holy hip hop politics. Online promotional materials for the event read: "Zyon is more than just an open mic. It is a place that offers a safe place for expression to artists, to the community, to activists, to those who are ready to see things change and are ready to make that happen." Avoiding any explicit links to Christianity in marketing and promotion, Cue's primary hope was to attract a range of diverse participants. Occasionally, some very unlikely artists took the mic. John Serrins (a.k.a. Johnny Cash), a white man in his twenties and member of Asylumz, wrote the following on a homemade flyer for the event: "Zyon is an open space for free expression, all who grab the mic are entitled to spit whatever they would like. All who grab the mic can speak their mind freely. No censorship. Klub Zyon does not share or promote ideas expressed by those who grab the mic. Klub Zyon is an event that is open to all, regardless of race, religion, gender, sexual orientation, socio-economical standing, style of clothing, and/or eye color."

Biblically speaking, Zion is known as the historic land of Israel symbolizing the Jewish people. More specifically, it is the Canaanite hill fortress in Jerusalem referred to in the Bible as the "City of David" and used to symbolize the city as a religious center. In a metaphoric light, it represents heaven as the final gathering place of true believers or any idealized, harmonious community-a utopia. Klub Zyon's name, therefore, acts as a symbol and promise of this biblical geography of spiritual home. Here, Zion is not the Garveyite's Africa or even the Rasta's Ethiopia; it is a feeling of oneness and homecoming that was created in a cultural center in one of L.A.s most iconic black neighborhoods-a neighborhood that has attracted such residents as Ray Charles and Ella Fitzgerald. 
Leimert Park was not always a black Mecca. The area bound by Rodeo Road on the north, 4th Avenue and Roxton Avenue on the east, Vernon Avenue on the south, and Crenshaw Boulevard on the west, was once home to soybean fields known as Rancho Ciénega o Paso de la Tijera ${ }^{39}$ until it was developed by Walter $\mathrm{H}$. Leimert in the late 1920s. Considered a model of urban planning with Spanish Colonial Revival homes and tree-lined streets, the village was originally inhabited by white families. After the Supreme Court officially ended racially restricting housing covenants in Los Angeles in the early 1950s, the effects of white flight-the loss of jobs, capital, and local businesses-afflicted many burgeoning black communities. Leimert Park suffered less than Watts, Willowbrook, and other South L.A. communities as a stronghold of successful African American professionals organized under the banner of Crenshaw Neighbors to help slow the inevitable process of white flight. Despite its image of black success, Josh Sides argues:

Leimert Park was not immune to the roiling changes of the 1970s and 1980s, decades in which African American poverty skyrocketed nationwide because of the disappearance of industrial work; in which gangs exploited idled young men; and in which highly-addictive and dangerous drugs hit the streets. And Leimert Park residents also faced the challenge of maintaining community cohesion, as the most prosperous residents moved up into Baldwin Hills. But the commitment of remaining residents to keep Leimert Park special never died. In 1967, brothers Alonzo and Dale Davis opened the Brockman Gallery, "the premier venue for exhibiting black art in the city," according to historian Daniel Widener, and the hub of a citywide black arts movement. Residents led clean-up committees to erase graffiti, blocked efforts to add liquor stores to the area, and organized political action committees. ${ }^{40}$

Black arts continued to thrive in Leimert Park with the addition of the World Stage performance center in 1989, a joint effort between jazz drummer Billy Higgins and activist Kamau Daáood. The Zambezi Bazaar, an African-themed arts and crafts store, opened in 1992 and in the same year, former Skid Row resident and African American veteran Richard Fulton opened Fifth Street Dick's Coffee House-a haven for music, chess, poetry, and comedy alike and where I conducted several interviews with gospel rappers. Caldwell's KAOS Network was among several burgeoning arts spaces in the area, and in 1997, Babe's and Ricky's Inn-a blues club originally housed on Central Avenue-moved in next door. Across the road, Leimert Park Plaza has housed an array of black-themed celebrations from Kwaanza to Malcolm X and Martin Luther King Day festivals.

The iconography adorning KAOS Network reflects Leimert Park's diasporic cosmos of art, community, and racial struggle. A large black and white photograph of Malcolm X and Muhammad Ali hangs in the storefront, consecrating the space as a cultural Mecca. Upon entering the small, intimate venue, three regal figures hold court: a painting of Nigerian musical and political legend Fela Kuti, a poster of bebop master Charlie Parker, and the image of a sphinx-like head bordered by 


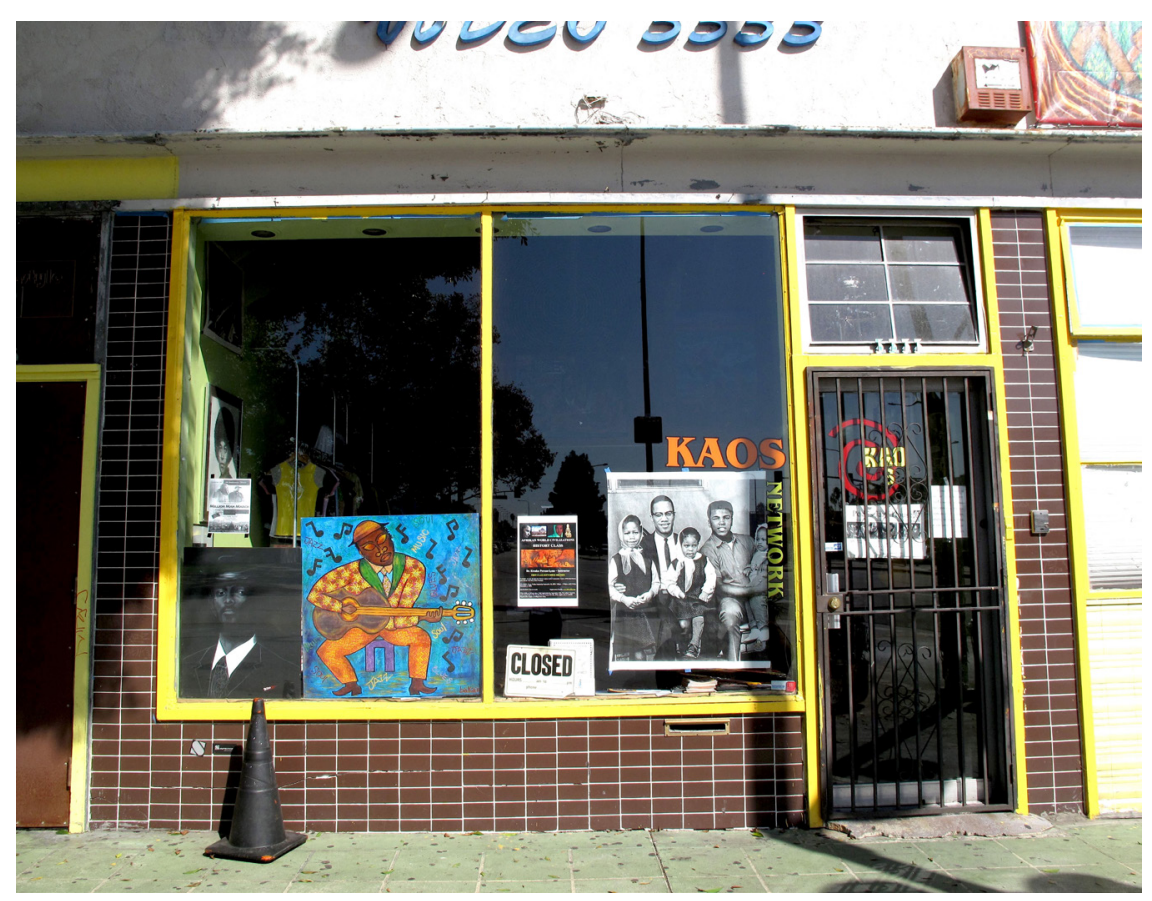

FIGURE 10. KAOS Network storefront in Leimert Park featuring a photograph of Malcolm $\mathrm{X}$ and Muhammad Ali. KAOS Network was home to both the underground hip hop freestyle event, Project Blowed, and the gospel hip hop open mic, Klub Zyon.

different hieroglyphs and figurines rendered in an Egyptian aesthetic. The interior décor paints a black Atlantic scene that links specific places and genres-Los Angeles, hip hop, Nigeria, afrobeat, Egypt, and bebop-across both real and imagined terrains of local and transnational crossing. During nights that I attended Klub Zyon, nothing was physically altered in the space except the sounds and bodies inhabiting it; the social, musical, and religious dimensions of Klub Zyon were what defined the event as distinct from its secular counterpart, Project Blowed. Although the majority of the performers were young African American males, I was always struck by the consistent diversity of the crowd, which included people of various socioeconomic classes, ages, sexual orientations, and religious, racial, and ethnic backgrounds, hailing from various Southland neighborhoods, and exhibiting a wide array of urban apparel and fashion-from understated in a T-shirt and jeans to what some may consider a Christian "ghetto fabulous" style.

Sonically, gospel hip hop artists subjected KAOS Network to the rhythms and sensibilities of hip hop music, rapping, freestyle, testimony, and prayer. DJ Heat, another member of Hip Hopposite and Christian rap radio DJ on Headz Up FM, 
would spin both secular hip hop beats and gospel rap songs throughout the evening-a curious choice given that many gospel rap artists avoid secular hip hop altogether. When playing secular hip hop tracks, he would only play the instrumental versions. But most crowd members were familiar with the lyrics of these well-known hits (e.g., Nas's “Whose World Is This?” or Outkast's “Player's Ball”) and traces of their somewhat unsavory associations sometimes seemed to linger in the room. DJ Heat never showed much emotion or energy while spinning records, projecting a stoicism often seen in church musicians who steadily and dutifully provide music to encourage congregants to catch the spirit.

An evening at Klub Zyon was divided into three distinct sections. Initially, after the host MC welcomed everybody with a short prayer, rappers took to the stage to freestyle (improvise rhymes) over hip hop beats of DJ Heat's choosing. Those who signed up early for the open mic were allowed to perform one or two "writtens" (precomposed rhymes or songs) either a cappella or over pre-recorded tracks that they generally brought in on CDs or iPods. The night concluded with a featured performance set by a local gospel hip hop artist or group. This format mimicked a typical church service found in many mainline denominations: a lively and participatory "Praise and Worship" section, followed by gospel music performances or praise dance, and ending with the main event of the sermon. The host closed the night with another short prayer before participants poured out onto the street corner for more fellowship and freestyling.

\section{“THIS AIN'T YOUR DADDY'S MUSIC”}

On a cool and clear November night in 2007 at Klub Zyon, Johnny Cash introduced TripLL-H (a member of the holy hip hop crew G-Boy Union) as the host MC for the night. Khanchuz quickly reminded me that, in holy hip hop, MC stands for "Minister of Christ," not "Master of Ceremonies" or "Microphone Controller," before he and Gandhi-an MC of small stature and South Asian descent-were summoned to the stage. Over a mix of hip hop beats curated by DJ Heat, Khanchuz delivered his rhymes with ferocity, kicking his leg up in the air and wearing a righteous scowl. His whole body compressed with conviction, his stomach becoming the fulcrum from which his chest and legs contracted. His flow was clear and well annunciated over a quintessential L.A. gangsta rap beat as he rapped, "Preaching heat in the streets like a ghetto apostle." Gandhi, surprisingly for his size, commanded a huge presence. His flow was sporadic, sometimes landing words right on the beat, other times falling just off it. Eventually, he lost his voice while rapping over his own prerecorded track. With a definitive head nod, TripLL-H confirmed: "This is how we do it for Jesus. We lose our voices for Jesus."

Statements like this were part of a larger effort to sacralize the space and inscribe a sacred meaning on the activities that shaped Klub Zyon, however secular 
they appeared. They also undergirded the desire and willingness to offer up one's body for the glorification of Jesus and the edification of the Body of Christ, even if one was ultimately rendered voiceless. In a similar manner, Young Chozen, a young black MC in his late teens, later shouted into the mic, "How many of you glad you got butts to shake? God is good." In one verbal move he celebrated both body and spirit, calling for butt-shaking as praise as he praised God for butts that shake. These were the unique body politics of Klub Zyon. Young Chozen, in particular, demonstrated an ability to intertwine religious and secular themes, thus appealing to both religious and secular audiences. His friendship with Wes Nile, another young male MC who frequented Klub Zyon, resulted in Wes Nile's eventual conversion to Christianity.

Many young folks of all backgrounds were "touched" by the music that took place at Klub Zyon. They felt blessed and inspired by the testimonies that gospel MCs delivered through their music. It gave them a new way to understand themselves as believers who could also participate in the cultural movement and musical language they knew so well: hip hop. This music gave young hip hop heads seeking God a way to belong as well as a way to become themselves amidst the radical upheavals and instability that permeated their everyday lives in Los Angeles.

Later in the evening, as it approached the midnight hour, Asylumz-the featured group consisting of six men in their twenties and thirties, hailing from Nigeria, Barbados, and the United States-brought house-wrecking contagion to KAOS Network with their original brand of "Worsh-Hop." ${ }^{41}$ A term used to represent Asylumz's unique sound, "worsh-hop" was a raw and embodied mixture of "praise and worship" music and hip hop.42 It was hip hop that intentionally glorified God, releasing transformative and ecstatic energies through the friction of the sacred and the profane. Following King David's triumphant assertion of his willingness to humiliate himself for the sake of his God, Asylumz claims they are willing to become "even more undignified" in their worshipping.

Raucously dancing across the stage, the members of Asylumz slammed into each other's bodies in praise. Their joyful, hyperkinetic energy was accompanied by a hard, masculine edge that matched the ear-splitting volume of the music. The instrumentals featured heavy-handed snare hits and pulsing high-pitched electronic notes over a dark synthesized bass drone. A chorus of men chanted militantly on the track, "Ay! Ay! Ay! Aaaaaaaay!" As the performance reached a crescendo, they jumped from the stage to the dance floor, colliding into audience members who also began chanting the song's hook: "This ain't your daddy's music! This ain't your mama's music! This is how I praise! This is how we praise! I'm a stomp and snap then whip that Cadillac. I know the Lord felt it cuz he didn't send it back."

Audience members-especially those who had been in the holy hip hop scene for a while-bobbed their heads and threw their hands in the air, clearly reveling 
in the opportunity to praise Jesus through hip hop beats, lyrics, and movements. This "Worsh-Hop" felt natural to them-a dynamic merging of their musical and religious sensibilities - and lifted them up not just in belief, but in community. But after the performance, Khanchuz explained to me: "I wasn't really feeling them tonight. I'm not gonna lie, it was entertaining, but I couldn't hear a word they were saying. For all I know, it could have been secular rap." For many gospel rappers, the message is the main factor that distinguishes holy hip hop from secular hip hop. Thus, sound levels, as they relate to the relative volumes of lyrics and beats, are a contested terrain in gospel hip hop. PK 100o's, a twenty-two-year-old African American male who frequents Klub Zyon, would often tell DJ Heat to turn his track down so that the audience could hear his lyrics. Once, I heard the sound engineer tell DJ Heat to drop the track out intermittently to highlight what the MCs were saying. Given these negotiations of musical dynamics, it is not surprising that interested passersby not familiar with the mission of Klub Zyon or the Christian orientation of its founders often mistook the sounds emanating from KAOS Network as secular, commercial, or even gangsta rap as opposed to holy hip hop. Such aural assumptions and misrecognitions were often what produced spontaneous, unexpected, and experimental moments of encounter-between gangsta rappers and gospel rappers, Muslims and Christians, prostitutes and pastors.

One such instance took place when an Asian American woman, Magita Passion, decided to take the stage at Klub Zyon. Her long, straight, and striking black hair was streaked with bleached blond and hot pink highlights. A short tattered pink shirt revealed her slightly bulbous belly_smooth and unashamed-as well as a large Chinese character tattoo that hovered just above black and white pinstriped pants belted by a red dragon-print satin ribbon. Her eyelids sparkled with burnt orange shadow while the stage lights reflected off her fuchsia patent-leather platforms. The crowd was unsure of what to expect from her. Magita, familiar with the location as the home of Project Blowed but unaware of Klub Zyon's Christian underpinnings, began a spoken word piece that revealed herself as a sex worker and advocate of sex worker rights (including the decriminalization of sex workers and the legalization of prostitution) to an audience comprised mainly of Christian hip hoppers. She further explained that, historically, people have been supporting themselves with the money they earn from sex work-in her words, "getting paid for making love" - but they have been marginalized and stigmatized by a society with double standards.

As Magita uttered the final words of her performance, a deafening silence swallowed the room. TripLL-H walked over and put his arm around her, then said ruefully, "We're going to pray for you." A Christian woman from the audience approached the stage, attempting to befriend her as members of the crowd shouted, "Plant that seed!" As Magita began to realize the spiritual nature of the event, she rolled her eyes in annoyance, retorting, "I don't need your prayers." Sensing that 
TripLL-H's "call to prayer" may not have been the most sensitive or affective response to her poem, the crowd began to encourage Magita to perform another song, hoping to restore Klub Zyon's environment of openness and tolerance. Deciding that she wasn't in the mood anymore, she left with the apology: "Sorry for crashing your church." Magita didn't want pity or prayers; she had just wanted to share her story through rhyme.

Despite the appearance of failure in terms of achieving Klub Zyon's vision for an all-inclusive space, this was just the kind of interaction that Cue was attempting to facilitate-for a non-Christian to walk into the mix, stir things up, and trouble the waters. This was the kind of productive trouble Cue was trying to get into during nights at Zyon. After Magita Passion left, Cue asked Mercy, another MC from Asylumz, to lead everyone in a prayer for her. He spoke of many things, but most strikingly, he prayed, "We ask for forgiveness, Lord, yours and hers, if we've offended her in any way. She is one of us. We are all the same. What I like about her, Lord, is that she is bold. Jesus needs bold people in the kingdom." Through this humble self-reflection, something was restored. Although TripLL-H and others' methods for bridging a religious divide did not prove to be successful in that moment, both the real and imagined geographies of Klub Zyon were remembered and re-visioned through this collective prayer and apology. The gospel rap that followed was less worshipful than it was healing. Again, holy hip hop became earthquake music. The rhythmic prayers and performances helped to navigate the shifting grounds of Klub Zyon-grounds wrought with moral and musical tensions as well as racial and religious fissures, grounds that many have struggled to transform into Meccas and Zions.

The stories relayed here highlight moments of interaction and transformation between diverse hip hop subjects and expose crosscutting interests and investments (e.g., artistic, political, religious, etc.) enacted in sites of holy hip hop. The walls of the building had less to do with the lived geography of Klub Zyon than the dynamic of musical interrelations that the event produced between diverse spatial bodies, human bodies, and anatomies of belief. That said, the fact that Klub Zyon took place in a well-respected location for "underground" hip hop battles gave credibility and accessibility to the event.

At Klub Zyon, unexpected brushes with the profane and brushes with the sacred suggested a contested yet ecological relationship between church bodies, club bodies, and the arteries of the streets. ${ }^{43}$ What happened in this time and place was less defined by the event producers than it was by the participants, audience, and passersby, thus broadening our conceptions of what we consider to be gospel rap and who we consider to be participants and cultural shapers of the scene. What can we draw from the relationship between the biographies and geographies of holy hip hoppers is that the very actualization of these sites was capable of diverting temporal itineraries and life courses, thus illustrating how for holy hip 
hoppers in Los Angeles a walk with God was in many senses a walk through the city. And along that walk, the seismic soundings of gospel rap moved the ground they walked on.

\section{CLUB JUDAH ALCHEMIES}

Club Judah was a weekly holy hip hop night housed at the Love and Faith Christian Center near Western and Manchester Avenues on the outskirts of Inglewood-the area where Mayor Bradley declared the first sunset-to-sunrise curfew on the second day of the 1992 riots. On Saturday nights, Pastor Colette Cruz and other Club Judah leaders rolled the pews to the outer edges of the room, set up large circular tables with black tablecloths, and dimmed the lights to create a clublike atmosphere for young people to experience God in a more hip, relaxed environment. Historically, black churches have been used for a number of sacred and secular activities. Historian Evelyn Brooks Higginbotham notes:

By law, blacks were denied access to public space such as parks, libraries, restaurants, meeting halls, and other public accommodations. In time the Black church-open to both secular and religious groups in the community-came to signify public space. It housed a diversity of programs including schools, circulating libraries, concerts, restaurants, insurance companies, vocational training, [and] athletic clubs-all catering to a population much broader than the membership of individual churches. The church served as meeting hall for virtually every large gathering. It held political rallies, clubwomen's conferences, and school graduations. ${ }^{44}$

Similarly, Pastor Colette Cruz made the Love and Faith Christian Center a gathering place for a wide range of activities. She initially created Club Judah for her adolescent daughter, who is a fan of hip hop music. The church's website reads:

"We're Spittin' Holy Fire! Club Judah began as a club for teens, a Christian alternative to what the world offers them on the weekends. Though teens are still the focus of Club Judah, it has expanded into much more. Each week now, Gospel Hip Hop artists from all over Southern California, and even some from out of state, come in to minister through heavy beats and even heavier Word based lyrics. The audience is not only entertained but also, and more importantly, edified by the Word of God." ${ }^{\prime 5}$ The event was free, because as Pastor Colette always said, "Jesus has already paid the cost."

Club Judah represented and enacted both historical and ongoing geographies of conversion. The spatial transformations that took place every Saturday night entailed a physical conversion of the church sanctuary into a club. While Club Judah was in session, the room remained very dark. The stage, which served as the pulpit area during regular church services, featured colored lights against a maroon curtain. The interior space, like the exterior of the building, was stark, unadorned, and boxy. At the end of the night, everyone present helped to dismantle and convert 


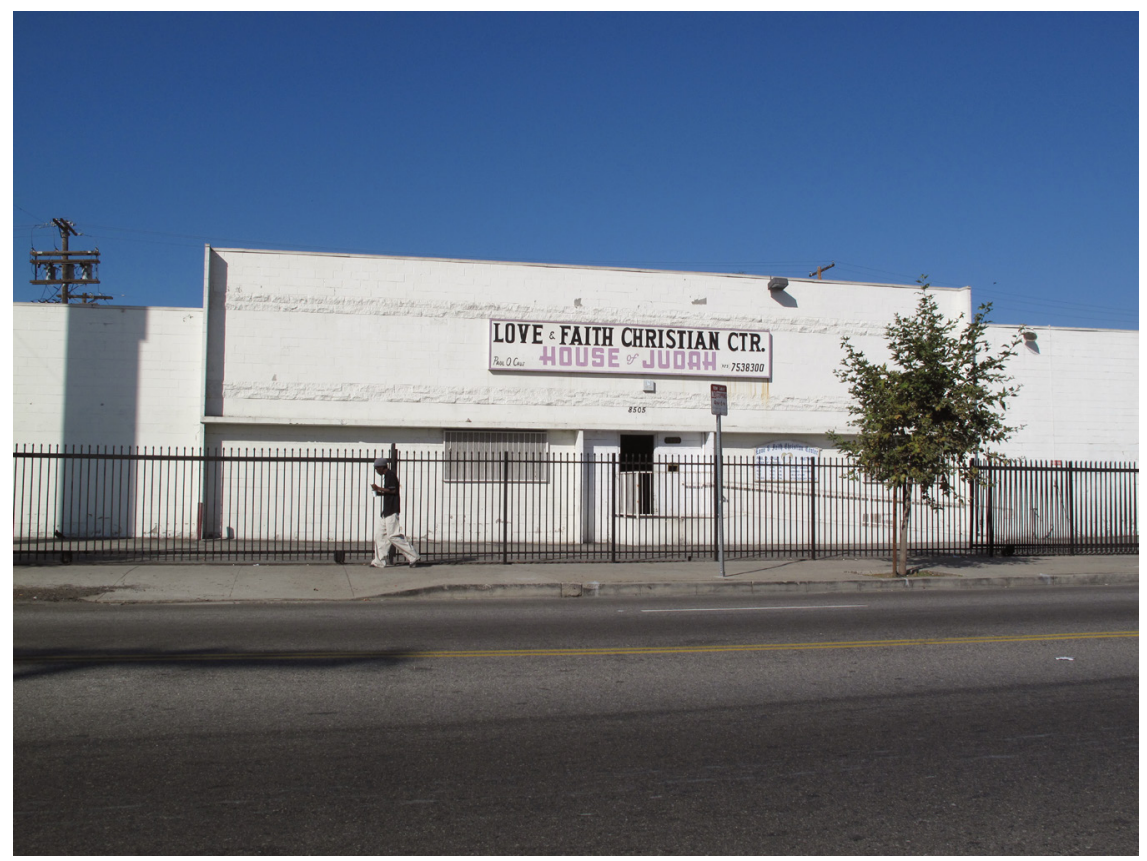

FIGURE 11. Love and Faith Christian Center at the corner of Manchester and Western Avenues. The church was home to the weekly hip hop praise night, Club Judah.

the club back into a church space for Sunday morning service. The fluorescent lights flickered on; those present folded up the tables and chairs and stacked them neatly in rows against the walls. Witnessing and partaking in the temporary, fleeting nature of the "club" space was surreal at times. The youth who were invited there in the hopes of religious conversion were also a part of the spatial conversion of the evening.

The Love and Faith Christian Center was formerly the site of a Western Surplus (gun store) before the building was looted and burned during the 1992 riots, the carcass then renovated into a place of worship. Undergoing a kind of urban alchemy, the plain, unassuming white façade of the building now reads "House of Judah." In the Bible, "Judah" is known as the fourth son of Jacob and Leah and the forebear of one of the tribes of Israel. The name originated in Leah's words of praise to the Lord on account of Judah's birth: "Now will I praise Jehovah, and she called his name Yehudah" 46 and is now known to mean "praised" or "praise." 47 Therefore, Club Judah quite literally means Club Praise-a club where one praises instead of parties and gets high on Christ instead of drugs or alcohol. In another diasporic twist, the building's backside features a mosaic-tiled mural featuring a lion. Multicolored bodies hold hands on either side of it. The Lion of Judah, while 


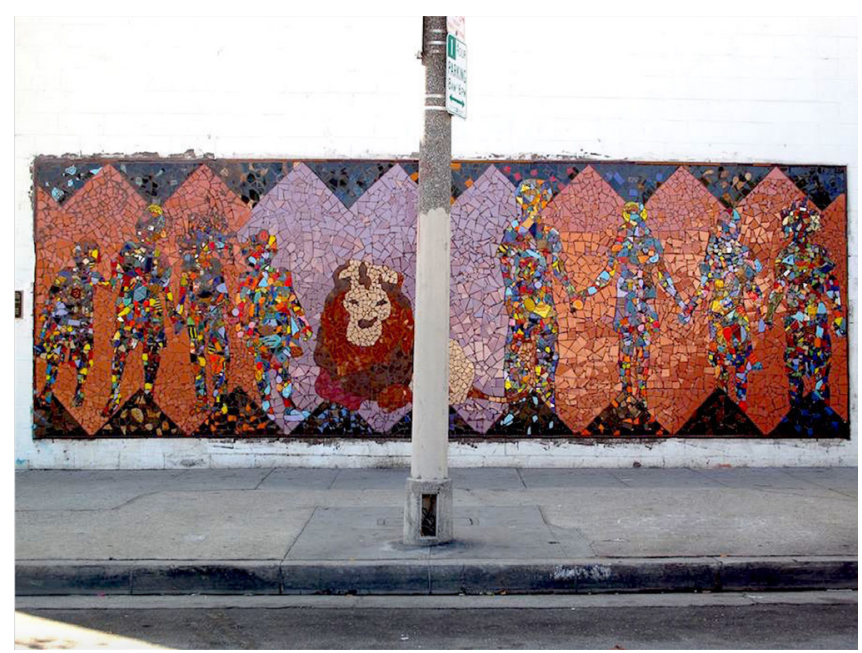

FIGURE 12. The Lion of Judah at the center of a mosaic-tiled mural on the side of the Love and Faith Christian Center.

sometimes a symbol of Jesus in the Christian tradition, is also a potent image for the Rastafarian movement and often depicted as golden and crowned. Dancehall reggae-inspired hip hop grooves, over which gospel rappers were "Spittin' Holy Fire," often graced the stage of Club Judah, further forging sonic and spiritual connections between black Atlantic religious cultures. Some of the holy hip hoppers in attendance participated in the rioting on those very same grounds fifteen years earlier before they were "saved." These were the everyday gospel rap alchemies that transformed gun metal into lion's gold. This was earthquake music in action, wherein within destruction also lies the possibility for creation.

Club Judah served as the location for many holy hip hop record release parties and anniversary events, as well as the destination for gospel hip hop artists visiting from outside the Los Angeles area. Attendees, mainly composed of African American families with children ranging from two to eighteen years old, often arrived early to hang out, play monopoly, basketball, or video games, shoot pool, and fellowship. Moving through these various stages and spaces of the evening was integral to the family-friendly experience of Club Judah-a space which at times functioned like a Boys and Girls Club.

For the year and a half that I frequented the event, Pastor Graham of Hood Ministries and Khanchuz hosted the evening program and often performed alongside other invited gospel hip hop artists. With tattoos and silver chains, both of these men embodied an aesthetic and an intimate knowledge of the streets. They often donned baggy camouflage pants, bandannas, and oversized hoodies. 
At first glance, they appeared more "gangsta" than "gospel," adding to their credibility among the youth. Khanchuz and Pastor Graham led attendees in a church/ concert hybrid, interspersed with prayer, musical performance, a short sermon, announcements, collective dance, and a final altar call. While they spit rhymes over their gospel rap tracks, little kids wandered onto the stage, danced freely, and bounced around waving church fans. The hard-edged, heavily synthesized beats brought in the unforgiving nature of the streets while the rhythmically rapped lyrics spoke of the Lord's grace in the midst of urban instability. That a church sanctuary could bring together and integrate these seemingly incongruous experiences for young people was powerful. The music seemed to both bring them into their pain and provide the cure for it.

I witnessed several youth give their life to Christ at Love and Faith Christian Center, undergoing a religious conversion in the nightclub-like space of Club Judah. In many ways, this was the penultimate expression of Pastor Graham's earthquake music-young folks so shaken and moved by the lyrics, beats, and righteous delivery of gospel rap that they would give their lives over to Jesus. But in the spring of 2008 , for undisclosed reasons, Pastor Graham decided he could no longer remain the host of Club Judah. Khanchuz stayed on for a while longer as a promise to the youth to maintain a consistent weekly space for them to congregate.

In 2008, on a sweltering summer night in Los Angeles, I strolled up to the blacktop parking lot in the back of the church. Young guys were playing basketball at the far end under the fluorescent street lamps. A group of young girls, Khanchuz's daughter Jaysha among them, locked my arms with theirs, forming a line of about five or six of us. They buzzed across the pavement like a swarm of bees, talking over each other and erupting with laughter. "Hey cousin, come on, follow us. We'll take you in," Jaysha reassured me, before yelling at the boys playing basketball to stop their dribbling and shooting so that we could pass in peace. Balls whizzed around us but my young escorts guided us through the cool light of the parking lot, parting the band of boys like the Red Sea. Once I was situated in the green room with Khanchuz, they made a quick dash back outside to continue their blacktop revelry. Having just woken from a nap, Khanchuz slowly dished up some fruit salad and water. I could tell that a long week of working two jobs had taken its toll on him. Like his name's transformation suggests-from Sleep to Khanchuzhe did not get much rest anymore. There was something a little gloomy about his energy and the building that night. It was the first time I had been to Club Judah since Pastor Graham had stepped down from his co-hosting duties.

Khanchuz confirmed that the space felt a bit depressing and heavy, partly because of Pastor Graham's absence and partly because of the weight that he feels the building carries. Quite literally, this site used to "pack a lot of weight" as it is weighted by sedimentations of racial discrimination and physical violence. Hindrances to the conversion of space, and perhaps souls, were attributed to unseen 
spiritual forces (e.g., the felt presence of the Devil), but also shaped by matrices of history, memory, and power. When holy hip hoppers created places of activity, those activities changed buildings just as the buildings carried meanings that molded the subjects within them.

\section{“BORN AGAIN" BODIES OF THE CITY}

Holy hip hop's geographies of conversion made visible certain "off the map" or "below the radar" activities and life stories of people living in predominantly black communities in Los Angeles as they sounded subterranean levels of urban existence and history that were concealed by the current topography of "church, motel, liquor store." The spatial practices of holy hip hoppers were not accounted for in conventional mappings of black L.A. Instead, they revealed the existence of multiple black L.A.'s that were much more complex and diverse than certain popular urban vocabularies articulated. This was the often invisible but audible city that holy hip hop sounded out.

Klub Zyon and Club Judah were not always clearly defined or physically permanent locations, but instead temporary, provisional, and overlapping social embodiments produced through a confluence of musical practices, evangelical methods, and spatial tactics. These events gave holy hip hoppers a way to belong, demonstrating that the power of gospel rap was oftentimes more about providing a sense of cultural and spiritual belonging than it was about reaffirming belief. But they also gave rap evangelists a way to interact with a wide range of city inhabitants at the crossroads of sacred and profane urban spaces.

During these nights of hip hop rapture, both the city and human soul were understood as "living architectures" capable of being rebuilt and reformed. Conversion was both undergone and enacted spiritually and spatially as holy hip hoppers converted street corners into airborne churches, houses of worship into hip hop clubs, and Babylons into Zyons. The forming of these rare urban configurations exposed the unfinished business of spiritual maturation as well as the unfinished geographies of Los Angeles - the bodies of the city "born again" - that at specific moments allowed for the creation of new kinds of social arrangements, subjects, and spaces. These sites were fleeting and, at times, blighted by their indefinite nature, but also provided the grounds for envisioning and embodying potential futures of racially, religiously, and intergenerationally integrated space.

Once again, conversion emerged as both a spiritual transformation and a multimodal practice of possibility within limitations. These holy hip hoppers realized it was possible to do something different on and with the bodies of the city than was specified by certain structures of power. ${ }^{48}$ At the same time, the territorial uncertainty of the Southland was also capitalized on by the state to enact and obfuscate the systematic displacement of certain city inhabitants, practices, and enterprises. 
The Zambezi Bazaar, often deemed the soul of the Leimert village, was purchased and closed in 2014 after the MTA (Metropolitan Transportation Authority) voted to put a rail stop in the village along its Crenshaw-LAX line. The Vision Theater is undergoing a multimillion-dollar renovation and fundraising campaign. While The Row-"The Church Without Walls" - still takes place every Friday night on a corner in Skid Row, Club Judah hosts events on a less regular basis. ${ }^{49}$ In 2016, Club Judah's church home-the Love and Faith Christian Center-relocated to a storefront on 54th Street near Crenshaw Boulevard, where the gospel hip hop event will hopefully re-emerge on new grounds. Klub Zyon, however, ceased holding open mics in 2009 due to lack of funds and communal support. These are the paradoxes of possibility and foreclosure that continue to permeate black L.A. 